\title{
Henry V at the Oregon Shakespeare Festival
}

\author{
by Gretchen E. Minton. Published in 2018 Issue 1.
}

For the production: Henry V (2018, Oregon Shakespeare Festival). Performance attended: 2018-08-29. See production details at the end of the review.

The PRACTICE Of PLANTING CAST MEMBERS AMONG THE AUdiENCE IS WELL-ESTABLISHED, BUT THE Oregon Shakespeare Festival manages to surprise at the opening of Henry $V$ nonetheless, for characters from all sides, and even in the lobby, begin with "O for a muse of fire" five minutes before the play is supposed to begin. Some seats are empty, audience members are still getting situated, and yet the Chorus has begun to speak. The actors stand up from their various locations and keep reciting the opening speech, but at their own paces, causing a striking dissonance. Once they fall silent and exit, attention turns to the actors who are slowly, and apparently with great effort, pushing the single set piece (built from a collection of grey rectangular boxes) in a counterclockwise direction. This slow, laborious pushing, taken over by others in turn, lasts an

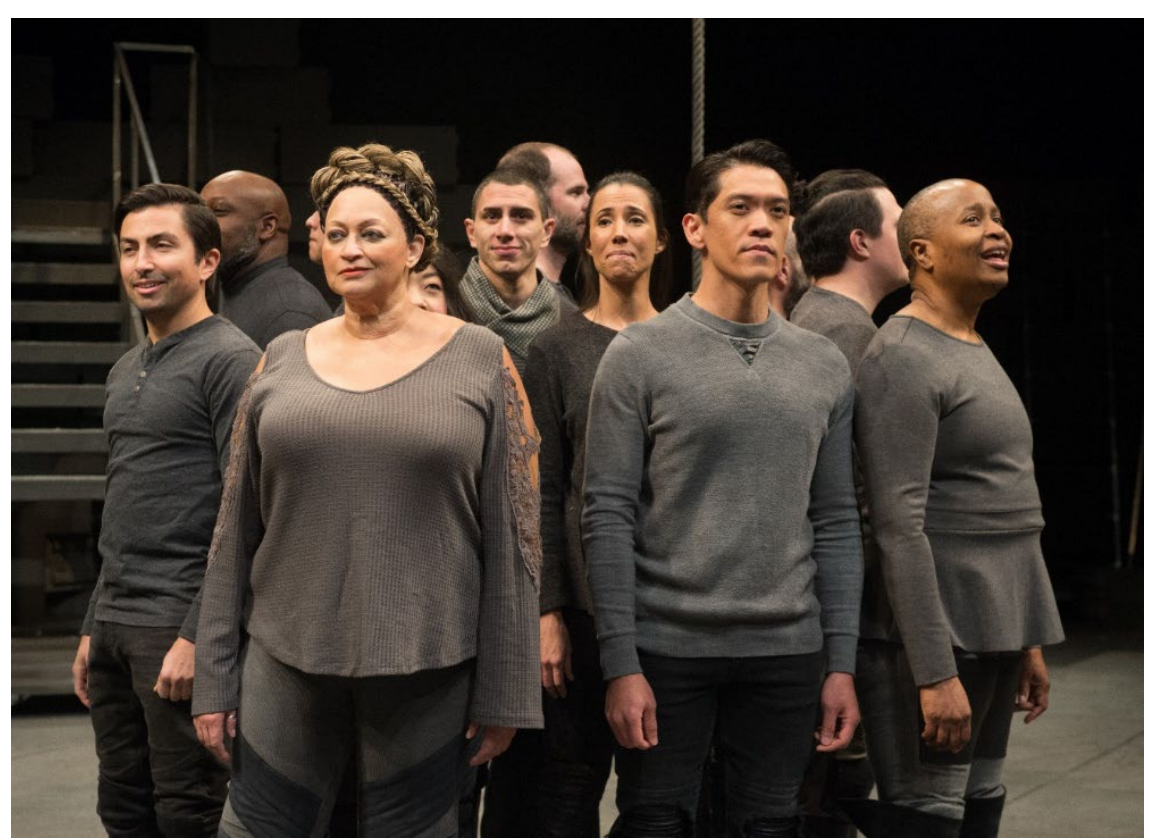

Figure 1. Ensemble as Chorus. Photo by Jenny Graham, Oregon Shakespeare Festival. uncomfortably long time, conveying a slow march backwards through the hourglass of medieval history. At last, all twelve actors from the cast move onto the Thomas Theatre's small stage, repeating the Chorus's opening speech, this time either together or serially; the discord and surprise of the earlier recitation are replaced by a unified voice.

This complex and provocative opening epitomizes the strength of OSF's 2018 staging of Henry V, which makes optimal use of the Thomas Theatre, employing the small cast with effective doubling of parts and constant movement. Like many companies, OSF had produced the Henry IV plays the previous year and cast the same actor in the Hal/Henry part in all three. However, 
this Henry $V$ was directed by Rosa Joshi as her first play at OSF, and thus the production had its own vision and was not unduly encumbered by the 2017 history plays. Nonetheless, this staging did in fact focus upon the collective weight and responsibility of war.

The costumes and set allowed for impressive versatility and swift scene changes. Actors regularly moved the boxes around the stage, which enabled the creation of boats, scaffolds, encampment stools, tables, and much more. Similarly, the actors wore a base layer of gray jeans, loose shirts, and black boots, over which robes, tunics, breast plates, and stocking caps could be placed, often in full view of the audience. In addition to being an expedient way to convey the story and its many characters with a small cast, the quick changes between English and French, or between nobility and commoners, reinforced the play's own interrogation of the differences between countries and peoples. The mingling of characters throughout the production made the assertions about the inseparability of soldiers' corpses on the battlefield easy to imagine.

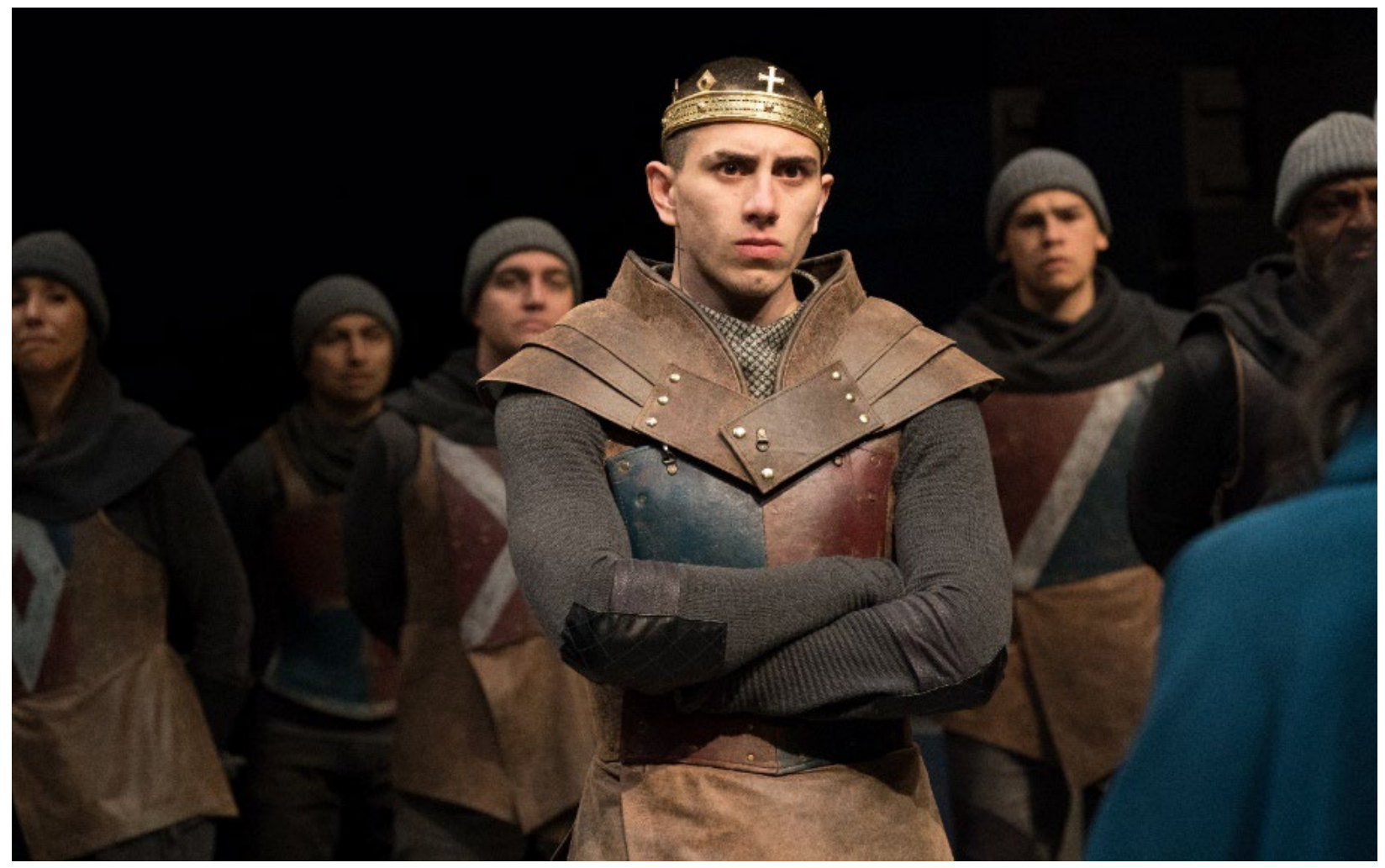

Figure 2. Daniel José Molina as Henry V, with Ensemble. Photo by Jenny Graham, Oregon Shakespeare Festival.

Daniel José Molina's Henry was young, with a shaved head and a cross tattoo on his neck that hinted at genuine religious fervor. He was earnest and quick to act, but demonstrative facial expressions betrayed his doubts. Stylized moments periodically slowed the action and helped to reinforce the moral ambiguity of the play. The Chorus's "little touch of Harry in the night" speech in Act 4 was accompanied by a slow-motion dumb-show that depicted Henry walking slowly 
across the stage while his men reached out to him and continued to hang onto him, so that he was symbolically dragging them across the stage, beset by the literal weight of his people. This image provided an excellent precursor to the "ceremony" soliloquy later in the act, where it seemed all too real that everything was being placed "Upon the king." Molina's Henry was more interesting when he showed weakness, as in the "ceremony" soliloquy, than when he attempted to create unity among his troops in the St. Crispin's Day speech. At the end of the Battle of Agincourt, he broke down sobbing, and Fluellan's joking about being Welsh seemed an attempt to be lighthearted so that Henry could regain composure.

The subplot involving Henry's former friends from Eastcheap lacked mirth, instead focusing on the tensions between characters and their dishonest impulses. But while there was no reason in this particular production to become attached to Bardolph, the stylized scene of his hanging was striking. Henry registered barely perceptible surprise at the name of the convicted soldier, but watched impassively as the execution took place. Bardolph ascended the stairs to a rope that was a permanent fixture of the set, then took off his jacket, placed it on a clothes hanger, and hung it from the rope as a red spotlight flooded the stage around him. As a ghost, Bardolph walked across the stage to Henry's white spotlight, but without pause he continued to exit. An especially strong performance by Rachel Crowl as Pistol was centered upon the moment that he saw his friend hanging from this rope and seethed with contempt for the whole war machine that created such an unnecessary death. Building upon that moment, Pistol's later extortion of money from his French prisoner was not funny but chilling, as was his cynical last speech.

Throughout the production red body suits were used to represent dead bodies-sometimes thrown across the stage or against the back wall, sometimes stretched to contorted positions. The killing of the boys guarding the luggage was represented by having one boy surrounded by French soldiers who violently threw red suits at the box on which he stood; each time a new round of red was thrown at him,

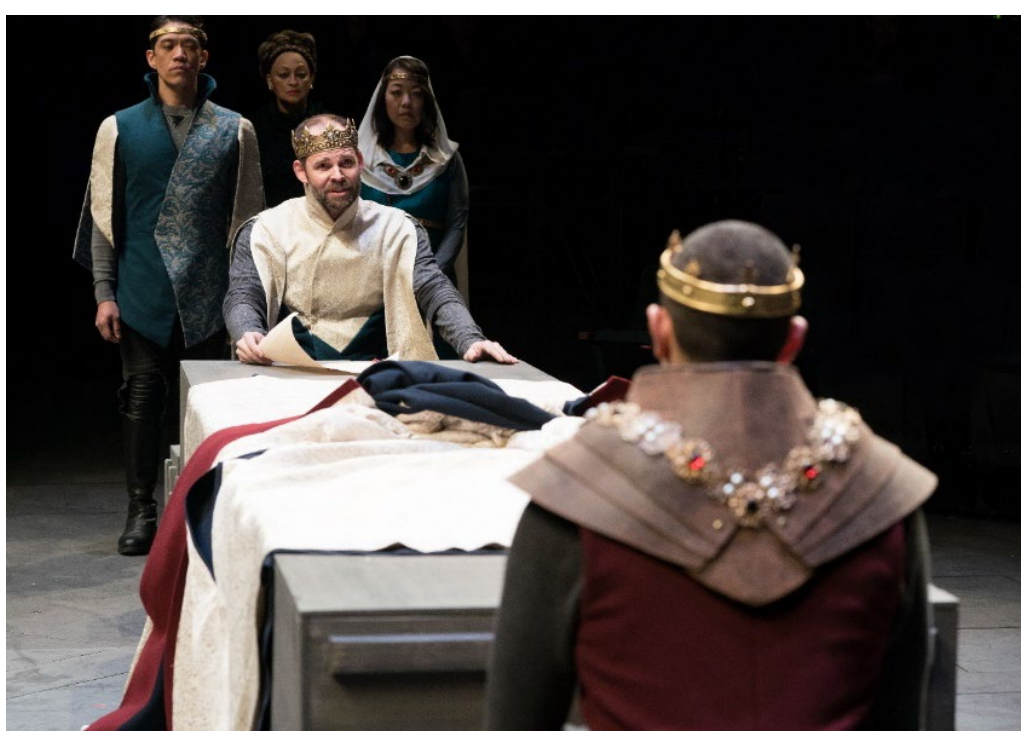

Figure 3. Moses Villarama as Lewis the Dauphin, Michele Mais as Alice, and Jessica Ko as Katherine (rear, left to right); Rex Young as the King of France (seated) and Daniel José Molina as Henry V (right foreground). Photo by Jenny Graham, Oregon Shakespeare Festival. 
he violently convulsed. The English soldiers sang the requiem as they carefully placed the red suits into the boxes, which had now become coffins; by the end of the song, however, these boxes had become a large table around which the French and English nobility sat to negotiate the peace.

Jessica Ko played the parts of the boy, Montjoy, and Princess Katherine, as well as leading the cast in the rendition of the non nobis song. Her performance provided a window into the impressive versatility of the cast. Ko's Katherine was self-assured and feisty during the language lesson, lacking any of the demure behavior that her character is often given. It was thus no surprise when she was the one who initiated the kiss in the wooing scene. Given the general seriousness of the production (despite some gentle amusement provided by Rex Young as Fluellan), the lightheartedness of the final scene was somewhat surprising. But although it may not have been a natural progression from what had preceded it, this levity helped to create the horrifying turn that the play took during the concluding Chorus speech.

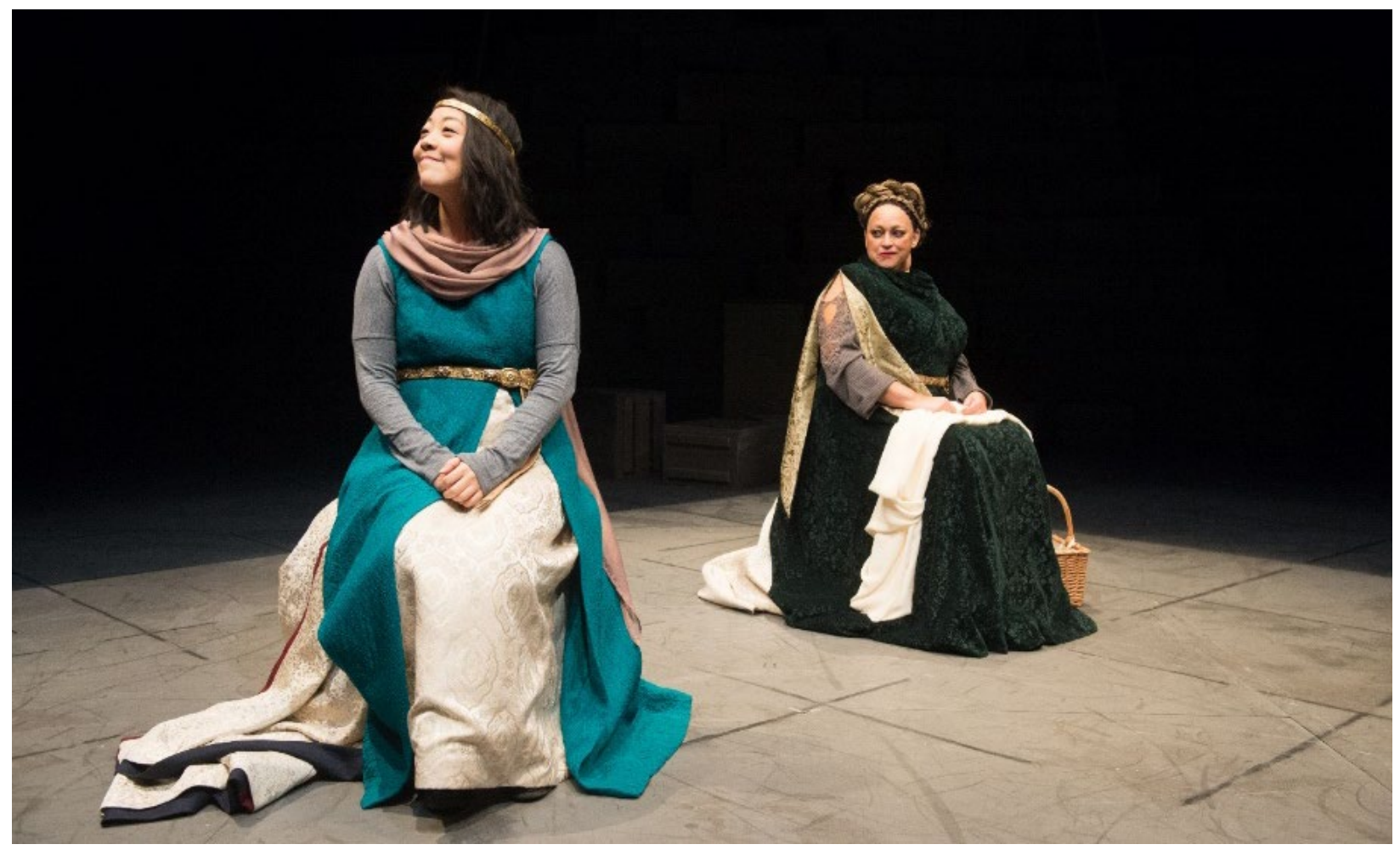

Figure 4. Jessica Ko as Katherine (left) and Michele Mais as Alice (right). Photo by Jenny Graham, Oregon Shakespeare Festival.

In the Folio text, Shakespeare laid the groundwork for the shift at the end of the play, deflating the sense of optimism by reminding the audience that Henry $\mathrm{V}$ died young, leaving his infant to inherit the throne, resulting in civil war and the loss of the hard-won French lands. In Joshi's production, the Chorus's final clause, "and made his England bleed," was followed by violent stage action that underlined this horrifying history. The actors all went to the stacked boxes that 
formed the back wall set piece, opening one after another, and violently threw the red body suits that they contained onto the stage floor in quick and chaotic succession while loud, dissonant music played. Even as the lights went down, the impression was clear: that every box was filled with more bodies, both those of past wars and those of future wars. The powerful conclusion thus conveyed that history is not only littered with corpses, but built upon them.

\section{Links}

Oregon Shakespeare Festival. https://www.osfashland.org/ 


\section{Production Details}

\section{General}

$\begin{array}{ll}\text { Title } & \text { Henry V } \\ \text { Year } & 2018 \\ \text { Theatre Company } & \text { Oregon Shakespeare Festival } \\ \text { Theatre } & \text { Thomas Theatre } \\ \text { Start Date } & 2018-02-21 \\ \text { End Date } & 2018-10-27\end{array}$

Cast

\begin{tabular}{|c|c|}
\hline KING HENRY V & DANIEL JOSÉ MOLINA \\
\hline Katherine, MONTJOY, Boy & JESSICA Ko \\
\hline Hostess QUiCKLY, Alice, FRENCH AMBASSADOR & MiCHELE MAIS \\
\hline CHARLES VI, FLUELLEN, ARCHBishop of CANTERBURY & REXYoung \\
\hline LEWIS THE DAUPHIN, GOWER, BISHOP OF ELY & Moses VilLaRma \\
\hline EARL OF SALISBURY, DUKE OF ORLEANS & SHYLA LEFNER \\
\hline NYM, JOHN BATES, EARL OF CAMBRIDGE & SHAUN TAYLOR-CORBETT \\
\hline BARDOLPH, MiCHAEL WiLLIAMS, LORD SCROOP & ROBERT VINCENT FRANK \\
\hline $\begin{array}{l}\text { DUKE OF BEDFORD, DUKE OF BURGUNDY, FRENCH } \\
\text { SOLDIER }\end{array}$ & JEREMY GALLARDO \\
\hline $\begin{array}{l}\text { PISTOL, SIR THOMAS GREY, GOVERNOR OF HARFLEUR } \\
\text { (FEB. 21-JUN. 8) }\end{array}$ & KIMBERLY SCOTT \\
\hline $\begin{array}{l}\text { PISTOL, SIR THOMAS GREY, GOVERNOR OF HARFLEUR (JUN. } \\
\text { 12-OCT. 27) }\end{array}$ & RACHEL CROWL \\
\hline DUKE OF EXETER & TYRONE WILSON \\
\hline $\begin{array}{l}\text { EARL OF WESTMORELAND, CONSTABLE OF FRANCE, } \\
\text { MACMORRIS, MESSENGER }\end{array}$ & CHRISTOPHER SALAZAR \\
\hline ENSEMBLE AND CHORUS & 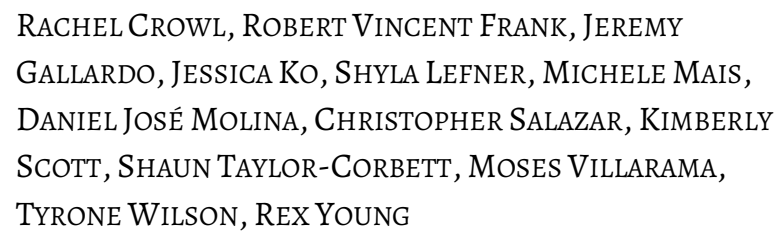 \\
\hline
\end{tabular}

\section{Creatives}

DIRECTOR

SCENIC DeSigner

COSTUME DESIGNER

LIGHTING DESIGNER
ROSA JOSHI

RICHARD L. HAY

SARA RYUNG CLEMENT

GEOFF KORF 


COMPOSER \& SOUND DESIGNER
CHOREOGRAPHER
PRODUCTION DRAMATURG
PRODUCTION DRAMATURG
VOICE/TEXT
FIGHT DIRECTOR
PRODUCTION STAGE MANAGER
PRODUCTION ASSISTANT

COMPOSER \& SOUND DESIGNER
PALMER HefFERAN

Alice Gosti

AMRITA RAMANAN

ALAN ARMSTRONG

DAVID CAREY

U. JONATHAN TOPPO

JILL RENDALL

TAIREIKCA L.A. 